\title{
Pisma Samuela Becketta, najveći epistolarni izdavački projekt našega vremena?
}

\section{Fehsenfeld, Martha Dow, et al., ur. The Letters of Samuel Beckett, 1929-1940. Cambridge UP, 2009. str. 782.}

Fehsenfeld, Martha Dow, et al., ur. The Letters of Samuel Beckett, 1941-1956. Cambridge UP, 2011. str. 791.

Craig, George, et al., ur. The Letters of Samuel Beckett, 1957-1965. Cambridge UP, 2014. str. 771.

Craig, George, et al., ur. The Letters of Samuel Beckett, 1966-1989. Cambridge UP, 2016. str. 838.

Samuel Beckett zapamćen je kao književnik koji je bio prilično rezerviran u odnosima s medijima. Pomno je čuvao svoju privatnost, rijetko javno nastupao te davao intervjue i izjave za medije. Njegova nam pisma, objavljena u četiri sveska u razdoblju između 2009. i 2016. godine u izdanju Cambridge University Pressa, stoga otkrivaju posve nepoznato lice književnika koji je korespondirao s izrazito velikim brojem osoba tijekom života. U arhivima i privatnim kolekcijama nađeno je oko 20000 pisama koja u potpunosti mijenjaju sliku Becketta kao pustinjaka. Pisma otkrivaju da je Beckett bio iznimno dobro povezan s poslijeratnim umjetničkim svijetom te u redovitom kontaktu s nizom bliskih osoba, poznanika i poslovnih suradnika, posebice u trenucima kad se zbog stvaralaštva povlačio u izolaciju.

Samuel Beckett četiri je godine prije smrti, 1985. godine, odobrio posthumno izdavanje svojih pisama. Zadatak je povjerio Marthi Dow Fehsenfeld, koja je potom zamolila Lois More Overbeck (Emory University) da joj asistira na tom opsežnom projektu. Uredničkoj su se ekipi ubrzo priključili George Craig (Sveučilište u Sussexu, prevoditelj) i Dan Gunn (profesor komparativne književnosti i 
engleskoga na Američkom sveučilištu u Parizu). Od početka rada na projektu naslovljenom „Korespondencija Samuela Becketta“ do objave prvog sveska pisama 2009. godine prošao je niz godina, zbog različitih prepreka s kojima su se urednici suočili. Među njima su bili rješavanje pitanja autorskih prava, činjenica da je Beckett urednike zamolio da osobno obiđu sve njegove (živuće) korespondente i upoznaju ih, obim korpusa i pitanje selekcije pisama za objavu te naposljetku, nečitljivost Beckettova rukopisa (zbog katarakte), što je dodatno otežalo transkripciju. Plod višegodišnjeg rada četiri su sveska odabranih, no ne i sabranih, pisama Samuela Becketta. U objavljeni korpus uvrštena su pisma koja je Samuel Beckett napisao u razdoblju između 1929. i 1989. godine, i to isključivo ona koja se izravno tiču njegova književnog stvaralaštva i nude informacije o stvaralačkim procesima. Beckett je izričito zabranio objavu pisama u kojima se spominju pitanja privatne naravi, tuđe nevolje ili se iznosi nečije „prljavo rublje“.

Priprema pisama za objavu bila je izazovan urednički zadatak. Pisma su bila razasuta po cijelom svijetu, po različitim arhivima, knjižnicama i privatnim kolekcijama pa je stoga njihovo prikupljanje trajalo godinama. Urednici su odlazili u arhive i knjižnice diljem svijeta te prepisivali pisma in situ. Brojne korespondente trebali su uvjeriti u kvalitetu projekta, steći njihovo povjerenje i privoljeti ih da im prepuste pisma za objavu. Pisma su godinama sakupljali, transkribirali, datirali, odabirali, prevodili te anotirali. Pisma su većinom napisana na angloirskom i francuskom jeziku, a manji dio na talijanskom i njemačkom. Sva su pisma objavljena na jeziku na kojem su izvorno napisana, s prijevodom na engleski jezik (pisma je s francuskoga na engleski jezik preveo Dan Gunn). Svaki je od četiri sveska popraćen popisom ilustracija, općim uvodom, predgovorom prevoditelja s francuskog jezika, napomenama o uredničkom poslu i načinu donošenja odluka, zahvalama, kraticama, uvodom u svaki pojedini svezak, profilima svih korespondenata, bibliografijom citiranih radova, fotografijama, kronologijom svake pojedine godine Beckettova života i indexom. Objavljeno je ukupno 2500 pisama, od oko 20000 nađenih. U bilješkama ih je spomenuto još 5000 .

Pisma iz prvog sveska napisana su u razdoblju od 1929. do 1940, tijekom kojeg Beckett dovršava studij na Trinity Collegeu u Dublinu, potom odlazi raditi kao lektor engleskog jezika na École Normale Supérieure u Pariz, vraća se u Dublin na radno mjesto asistenta na Trinityju, piše monografsku studiju o Proustu i svoje prve književne tekstove, putuje po Njemačkoj šest mjeseci te naposljetku seli u Pariz. Sabrana pisma zainteresiranim čitateljima nude uvid u Beckettov 
svakodnevni život na relaciji između Dublina, Londona i Pariza. Otkrivaju prisnog, srdačnog, duhovitog i ponekad bezobraznog mladog čovjeka koji pokušava pronaći vlastiti umjetnički put. Često se selio te mnogo putovao pa je pismima održavao kontakt s članovima obitelji i brojnim prijateljima (Nancy Cunard, Peggy Guggenheim, Jackom Butlerom Yeatsom, Cissi Sinclair, Nualom Costello, Morrisom Sinclairom itd.). Pisma iz prvog sveska svjedoče o Beckettovim naporima da objavi prve tekstove, da se realizira kao pisac te kako se suočavao s književnim kritikama koje su se pojavile nakon objave More Pricks Than Kicks i Murphy. Čitatelj kroz sadržaj pisama može upoznati Beckettov umjetnički, glazbeni i književni ukus, kao i stajališta o drugim književnicima. Najviše pisama iz prvog sveska upućeno je bliskom prijatelju Thomasu McGreevyju, kojeg je naslijedio na poziciji lektora na École Normale Supérieure u Parizu. Mladi Beckett iz prvog sveska želi da ga se doživljava kao pjesnika, a o pisanju proze, i posebice drama, ni ne razmišlja.

U drugom su svesku sabrana pisma iz razdoblja između 1941. i 1956. godine, kad se sa svojom životnom partnericom Suzanne Dechevaux-Dumesnil tijekom Drugoga svjetskog rata skrivao u francuskoj pokrajini Vaucluse, potom radio za Crveni križ u gradiću Saint-Malo, uključio se u svakodnevni život u Parizu nakon rata, pisao romanesknu trilogiju i U očekivanju Godota, kupio kuću u Ussy-sur-Marne te odlučio pisati isključivo na francuskom jeziku. Najveći broj objavljenih pisama čine ona koja je razmjenjivao s izdavačima, urednicima te redateljima i prevoditeljima svojih tekstova, a koja ujedno svjedoče o transformaciji nepoznatoga avangardnog autora u klasika 20. stoljeća, kao i transformaciji anglofonog prozaičara u frankofonog dramatičara. Dopisuje se s nizom prijatelja, među kojima su i Denis Devlin, Brian Coffey, George Reavey, a glavni korespondent mu je Georges Duthuit, likovni kritičar i Matisseov zet s kojim je bio blizak prijatelj od 1947. godine. Pisma objavljena u trećem svesku obiluju informacijama o Beckettu dramatičaru i Beckettu kazališnom redatelju. Otkrivaju autora koji je iznimno zaposlen, koji puno režira, piše i snima. Nakon uspjeha romaneskne trilogije (Molloy, Malone umire, Neimenovljivi) i četiri drame (U očekivanju Godota, Svršetak igre, Divni dani, Posljednja vrpca) zadržava visoku razinu produktivnosti i aktivnosti te se okreće književnom minimalizmu. Krug njegovih korespondenata u trećem se svesku proširio. Bio je u kontaktu s brojnim suvremenim umjetnicima, književnicima, redateljima, prevoditeljima, filolozima i književnim kritičarima, među kojima su John Calder, Ruby Cohn, Martin Esslin, Patrick Magee, Harold Pinter, Billie Whitelaw, Jacoba Van Velde, Bram Van 
Velde, Pamela Mitchell, Walter Asmus, James Knowlson te njegovi francuski i američki urednici Jérome Lindon i Barney Rossett. Trudio se da njegovi tekstovi u najboljem mogućem obliku dođu do publike i pomno je pratio njihovu recepciju nakon objave. U pismima je komentirao rad redatelja koji su na scenu postavljali njegove drame, tekstove književnih kritičara, pogotovo onih za koje drži da su neispravno shvatili njegov rad, a čitatelj saznaje i kako se nosio s književnim nagradama, pohvalama i pozivima na sudjelovanje na različitim događajima. Dio Beckettovih korespondenata bio je stalan, višegodišnji, a dio povremen. Ključni je korespondent trećeg, kao i četvrtog sveska, Barbara Bray, urednica drame na BBC-ju, kazališna kritičarka, producentica i prevoditeljica koju je upoznao dok je za Radio BBC pisao Embers i s kojom je godinama bio u ljubavnoj vezi. U četvrtom svesku okupljena su pisma koja je Beckett napisao tijekom posljednjih dvadesetak godina života, tijekom kojih nastavlja neumorno raditi, unatoč starosti i bolesti. Razdoblje je obilježeno dodjelom Nobelove nagrade 1969. godine, pojačanim medijskim zanimanjem s kojim se teško nosi te radom na tekstovima iz posljednje faze: Not I, Footfalls, Rockaby, Catastrophe, Quad, Company i Worstward Ho.

Četiri sveska odabranih Beckettovih pisama, protivno figuri izolirana umjetnika koja je nastala na temelju njegova odbijanja kontakata s medijima, otkrivaju umjetnika koji je redovito bio u kontaktu s obitelji i prijateljima u Irskoj kao i s brojnim suradnicima te koji se, posljedično, nametnuo kao jedan od najznačajnijih književnih korespondenata svoga vremena. Samuel Beckett dnevno je pisao i po desetak pisama. Sva su objavljena pisma iznimno precizno anotirana i nude obilje informativnih i zanimljivih podataka o kontekstu u kojem su napisana. Sa žaljenjem možemo konstatirati da su izgubljena pisma Suzanne te Beckettovoj majci i bratu, za koja se pretpostavlja da in je sâm uništio. U pripremu objave odabranih Beckettovih pisama uložen je iznimno veliki trud i rad te je stoga ovo nesumnjivo jedan od najvećih izdavačkih epistolarnih projekata našeg vremena, koji u paru s autoriziranom biografijom Jamesa Knowlsona (Damned to Fame: the Life of Samuel Beckett , 1996) čini nezaobilazni uvod za sve one koje zanima Beckettova biografija i stvaralaštvo.

Preostaje nam iščekivati prijevod na hrvatski jezik.

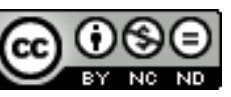

Creative Commons Attribution-NonCommercial-NoDerivatives 4.0 International License 